\title{
A new genus and species of hermit crab (Crustacea: Anomura: Paguroidea) from northwestern Australia
}

\author{
Patsy A. McLaughlin \\ Shannon Point Marine Center, Western Washington University, \\ 1900 Shannon Point Road, Anacortes WA 98221-9081B, U.S.A. \\ e-mail: hermit@fidalgo.net
}

\begin{abstract}
A new genus and new species of the hermit crab family Paguridae are described and illustrated from specimens collected off northwestern Australia. The genus, Cycetopagurus, gen. nov., is distinguished by a combination of characters shared individually with several genera that are collectively recognized by the development in males of an elongate right and a short left sexual tube, and the presence in females of paired and modified first pleopods. However, the armature of the telson of the type species, Cycetopagurus morgani sp. nov, of the new genus that consists of corneous spines is reminiscent of the family Parapaguridae.
\end{abstract}

\section{INTRODUCTION}

Among the materials still on loan to the late Mme Michèle de Saint Laurent, Muséum national $\mathrm{d}^{\prime}$ Histoire naturelle, Paris, were eight specimens of a new genus and species from the collections of the Western Australian Museum. Although recognized by de Saint Laurent, these taxa were still unreported at the time of her death. This material now has been entrusted to the author for formal description.

Some of the specimens are poorly calcified, and the majority of appendages are disarticulated. The specimen selected as the holotype does have three ambulatory legs still attached to the cephalothorax, and the abdomen is only slightly damaged. It has been possible to determine, with reasonable confidence, which of the detached chelipeds and remaining pereopod belong to the holotype. Despite the relatively poor condition of the remaining specimens, all are considered paratypes, as the distinctive characters of these bodies and appendages confirm their conspecificity. The genus adds yet another piece to the evolutionary puzzle of pagurid genera that have developed male sexual tubes. All specimens have been returned to the Western Australian Museum (WAM).

\section{TERMINOLOGY}

Gill structure is interpreted according to the definition of Lemaitre (2004); the criterion for sexual tube length is that proposed by McLaughlin (2003a). All other terminology for the diagnosis and description follows that of McLaughlin (2003b). The shield length (sl), as measured from the tip of the rostrum to the midpoint of the posterior margin of the shield is an indication of animal size; however, as is the case in a few paguroid genera, shield width increases disproportionately to length in the type species, rendering the shield length less informative that would be expected. The ratio of corneal diameter to length of the ocular peduncle has been obtained by measuring the length of the left ultimate peduncular segment, including the cornea, along the lateral surface; corneal diameter is the maximum measured dorsal width of the left cornea. The abbreviations stn and ovig. are used for station and ovigerous, respectively.

\section{SYSTEMATICS}

\author{
Family Paguridae Latreille, 1802 \\ Cycetopagurus gen. nov. \\ Figure 1
}

\section{Type species}

Cycetopagurus morgani sp. nov., gender masculine.

\section{Diagnosis}

Eleven pairs of biserial phyllobranchiate gills. Rostrum well developed, broadly triangular. Ocular acicles subrectangular to subovate. Antennal peduncle with supernumerary segmentation. Mandible (Figure 1a) with corneous tooth and 1 to few calcareous denticles on incisor inner margin. Maxillule (Figure 1b) with external lobe of endopod weakly developed, not recurved. Maxillule (Figure 1c) with elongate, slender endopod overreaching distal margin of scaphognathite. First maxilliped (Figure 1d) with basally swollen, distally slender exopod. Second maxilliped without distinguishing 

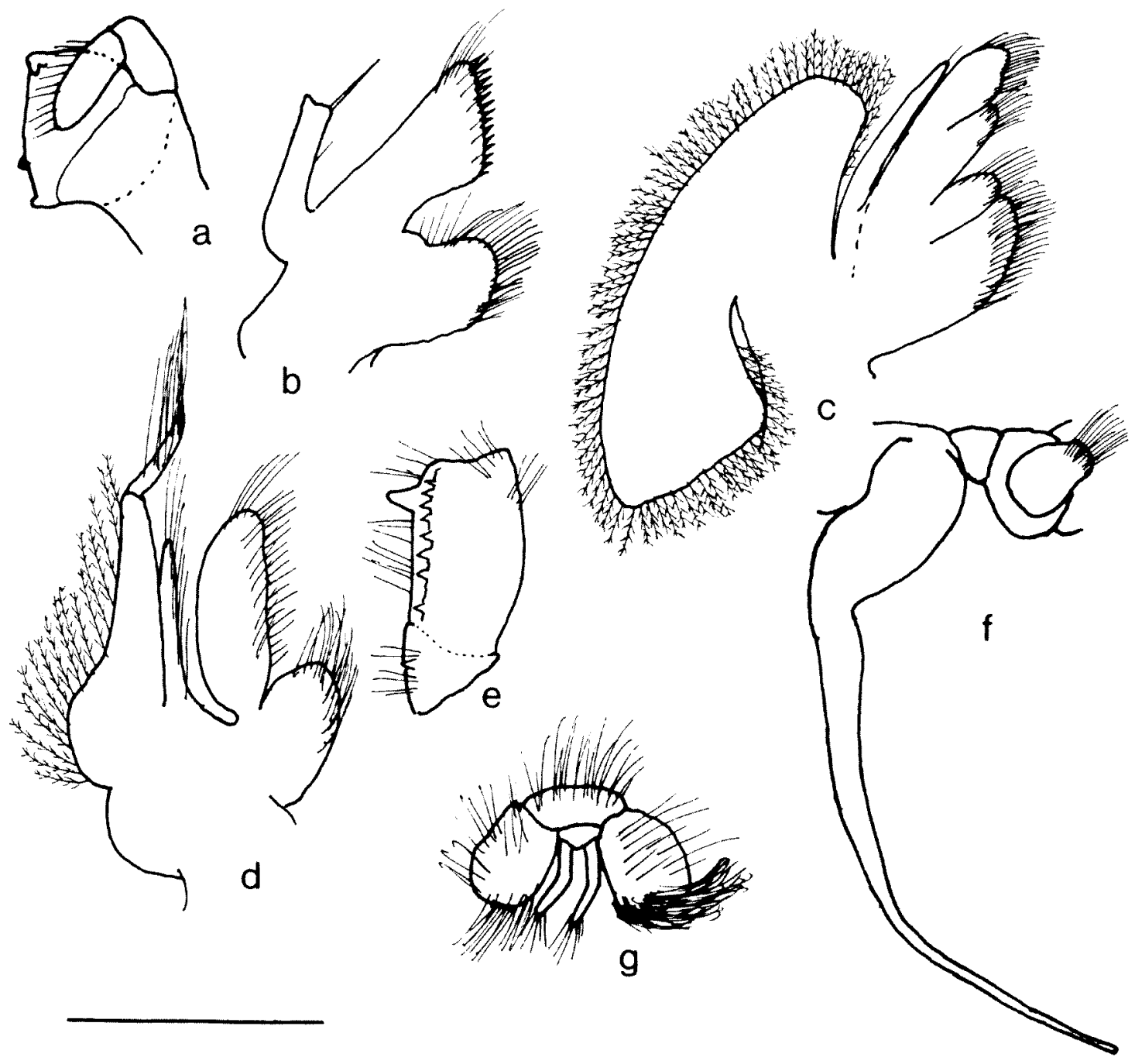

Figure 1 Cycetopagurus morgani, gen. nov., sp. nov., a-e, g, female paratype (sl = $3.2 \mathrm{~mm}$ ) WAM C33803, $\mathrm{f}$, male holotype (sl = $3.0 \mathrm{~mm}$ ) WAM C33802: a, mandible (right, internal view); $b$, maxillule (right, external view); $c$, maxilla (right, external view); d, first maxilliped (right, external view); e, basis-ischium of third maxilliped (right, internal view); $f$, coxae of fifth pereopods; $g$, coxae of fifth pereopods and paired first pleopods. Scale bar equals $1.0 \mathrm{~mm}(\mathrm{a}-\mathrm{e})$ and $2.0 \mathrm{~mm}(\mathrm{f}, \mathrm{g})$.

characters. Third maxilliped with crista dentata somewhat reduced (Figure 1e), but with prominent accessory tooth.

Chelipeds elongate, subequal, right stouter, but often shorter. Sternal plate of third pereopods broad, median hinge narrow. Fourth pereopods semichelate; with single row of spiniform, corneous scales in propodal rasp; dactyl without preungual process.

Coxae of fifth pereopods in males asymmetrical, right with long sexual tube (Figure 1f) directed posteriorly and externally, stout proximally, elongate and extremely filiform distally; left with very short, stout sexual tube; unequally biramous, unpaired, markedly reduced left pleopods 3-5. Females with paired gonopores, paired and modified first pleopods (Figure 1g), and unpaired left pleopods 2-5.

Telson with weak transverse indentations separating anterior and posterior portions; anterior lobes each with marginal spiniform bristles; rounded posterior lobes separated by distinct median cleft, terminal and lateral margins armed with comeous spinules.

\section{Etymology}

From the Greek kyketes meaning mixer, and paguros meaning crab. The name is chosen to reflect the combination of diagnostic characters that this genus shares with several other paguroid genera.

\section{Remarks}

In the development of the very elongate and terminally filiform right male sexual tube directed posteriorly and toward the exterior, Cycetopagurus gen. nov. is quite similar to Nematopaguroides Forest and de Saint Laurent, and Pseudopagurodes 
McLaughlin. However, in the latter two genera the rostrum is reduced or broadly rounded. But more importantly, females of the both genera lack paired and modified first pleopods, while females of Cycetopagurus are provided with them as are females of Nematopagurus A. Milne-Edwards and Bouvier, Michelopagurus McLaughlin and several other pagurid genera. The development of a corneous tooth and one or more calcareous denticles on the incisor process of the mandible is a character Cycetopagurus shares with Bythiopagurus McLaughlin, although the calcareous denticles are developed on the inner incisor margin in Cycetopagurus and on the upper incisor margin in Bythiopagurus. The elongation of the left cheliped in Cycetopagurus morgani, sp. nov., with the tendency of the fingers to curve ventrally is reminiscent of left cheliped development in Catapagurus franklinae McLaughlin, 2004. In both species, the length of the left cheliped occasionally exceeds that of the right, although the latter is always stouter.

By far the greatest number of shared characters is seen between Cycetopagurus, gen. nov., and the also monotypic genus, Icelopagurus McLaughlin. Both type species have short, stout ocular peduncles and well developed rostra. In both species the crista dentata of the third maxilliped is somewhat reduced, but the accessory tooth is prominent; the sternites of the third pereopods are broad and platelike. Males of both genera have moderate to long right sexual tubes and very short left tubes. The most significant shared character is seen in the armature of the telson, which consists of a row of corneous spines on each terminal margin. Corneous telsonal spines are common in the Parapaguridae (e.g., Lemaitre, 1994, 1996, 1999), but in the Paguridae such spines are reported only for Icelopagurus and now Cycetopagurus. However, in 1. crosnieri McLaughlin, 1997, these spines are long, few in number, and do not extend onto the lateral margins of the posterior lobes. In contrast, the spines in C. morgani, sp. nov., are short, numerous, and extend the full lengths of the terminal and lateral margins. Despite these similarities, the two taxa are readily distinguished. The ocular acicles of I. crosnieri are elongate and slender, as are the dactyls and propodi of the ambulatory legs; the right male sexual tube is not terminally filiform, and females lack paired and modified first pleopods. As the following description of C. morgani indicates, the ocular acicles of this species are subrectangular or subovate and not particularly long; the dactyls and propodi of the ambulatory legs are not notably elongate; the right male sexual tube is terminally filiform, and females have paired and modified first pleopods. Additionally, the lateral and mesial faces of the carpi of both chelipeds, at least in males of C. morgani, are ornamented with few to numerous capsulate setae
Cycetopagurus morgani sp. nov. Figures 1,2

\section{Type locality}

NW of Camarvon, off Cape Cuvier, Western Australia, $24^{\circ} 04^{\prime} \mathrm{S}, 11252 \mathrm{E}$

\section{Holotype}

o $(\mathrm{sl}=3.0 \mathrm{~mm})$ (WAM C33802), CSIRO stn Dm 6/192/63, 2404'S, 11252'E, 140 m, 8 October 1963.

\section{Paratypes}

$2 \delta(\mathrm{sl}=2.8,2.9 \mathrm{~mm}), 2$ ovig. $q(\mathrm{sl}=3.0,3.2 \mathrm{~mm})$ (WAM C33803), CSIRO stn Dm 6/192/63, 240.'S, $112^{\circ} 52^{\prime} \mathrm{E}, 140 \mathrm{~m}, 8$ October 1963.

3 d? $(\mathrm{sl}=2.4-3.0 \mathrm{~mm})($ WAM C 33804), CSIRO stn $\mathrm{Dm} / 187 / 63,23^{\circ} 39^{\prime} \mathrm{S}, 113^{\circ} 12^{\prime} \mathrm{E}, 134 \mathrm{~m}, 7$ October 1963.

\section{Description}

Shield (Figure 2a) as long as broad or slightly broader, weakly to moderately well calcified, slightly vaulted; anterior margin between rostrum and lateral projections nearly straight to weakly concave; anterolateral margins sloping; posterior margin truncate; dorsal surface with scattered short setae. Rostrum prominently produced, broadly triangular, terminally subacute, reaching to midlength of ocular acicles. Lateral projections obsolete or nearly so, unarmed or each with minute spinule. Carapace lateral lobes narrow to moderately broad, weakly to moderately well calcified. Posterior carapace median plate membranous or weakly calcified anteriorly, membranous posteriorly; posterior carapace lateral plates usually weakly calcified for almost entire length; cardiac sulci and sulci cardiobranchialis extending nearly to posterior carapace margin.

Ocular peduncles short and stout, $0.3-0.5$ length of shield; corneas prominently dilated, corneal diameter $0.6-0.8$ of peduncular length. Ocular acicles subrectangular to subovate, terminating bluntly or subacutely, but each with distinct submarginal spine; separated basally by breadth of rostrum.

Antennular peduncles, when fully extended, overreaching ocular peduncles by slightly less to slightly more than entire lengths of ultimate peduncular segments. Ultimate segment with 1-4 long, simple setae on dorsal surface distally. Penultimate segment with occasional, short setae. Basal segment with spine on dorsolateral margin.

Antennal peduncles, when fully extended, overreaching ocular peduncles by at least 0.2 lengths of penultimate segments. Fifth and fourth segments with few scattered setae. Third segment with tufts of setae on ventrodistal margin, and sometimes also very small spinule. Second segment with dorsolateral distal angle produced, 


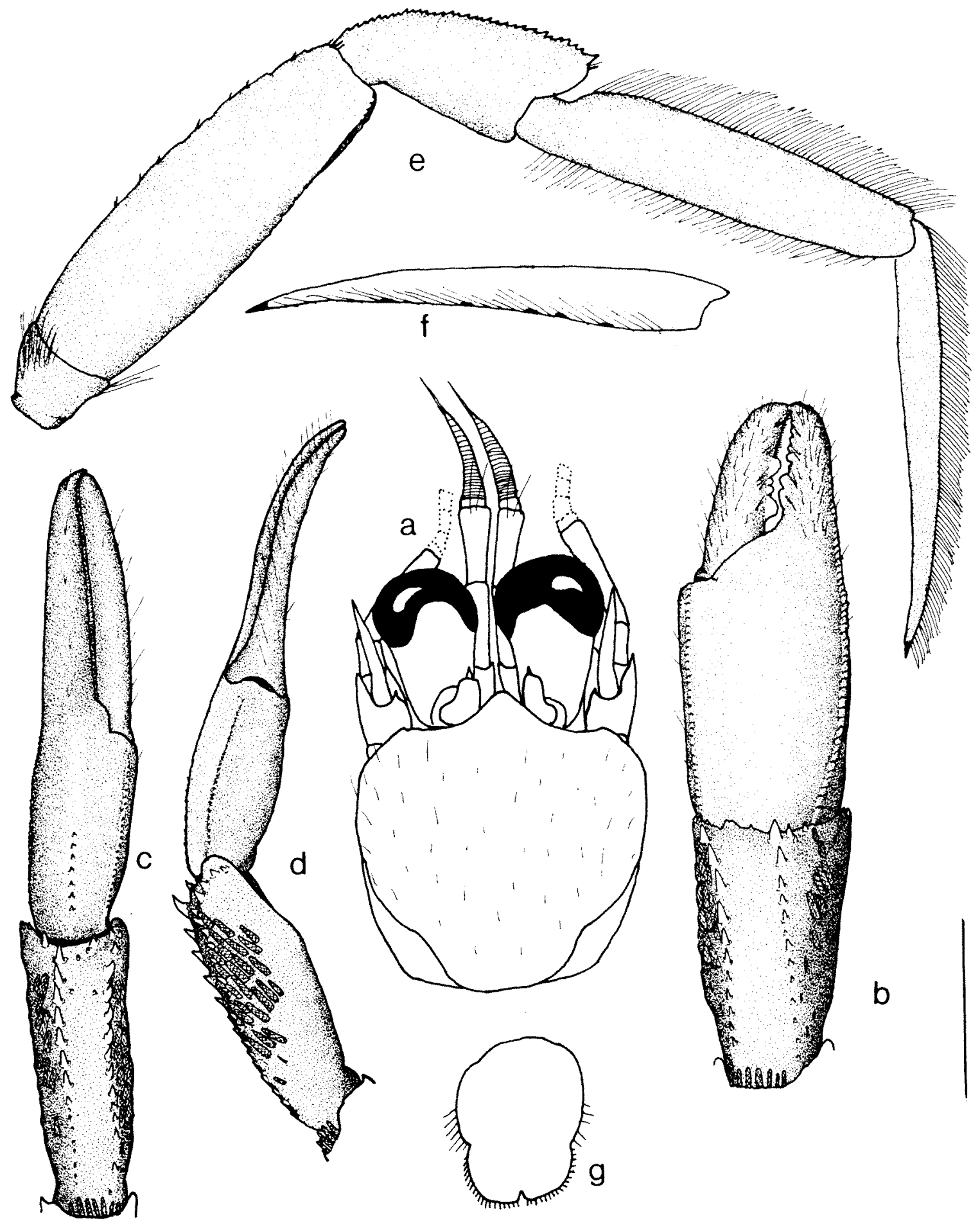

Figure 2 Cycetopagurus morgani, gen. nov., sp. nov., male holotype WAM C33802: a, shield and cephalic appendages (aesthetascs omitted); $b$, chela and carpus of right cheliped (dorsal view); $c$, chela and carpus of left cheliped (dorsal view); $d$, chela and carpus of left cheliped (mesial view); e, right second pereopod (lateral view); $f$, dactyl of right second pereopod (mesial view); $g$, telson. Cross-hatched setae represent capsulate setae. Scale bar equals $1.0 \mathrm{~mm}(\mathrm{~g})$ and $2.0 \mathrm{~mm}(\mathrm{a}-\mathrm{f})$.

terminating in simple spine; dorsomesial distal angle with well developed spine. First segment unarmed. Antennal acicle reaching beyond distal margin of fourth peduncular segment; terminating in acute spine; mesial margin with few moderately long setae. Antennal flagellum (missing in holotype and most paratypes) long but usually not longer than ambulatory legs, naked or with very few short setae on proximal articles. Sternite of third maxillipeds with median concavity, unarmed.

Chelipeds subequal; right stouter, but often slightly shorter than left. Right cheliped (Figure 2b) 
with dactyl 0.7-0.8 length of palm; dorsomesial margin rounded, unarmed but with row of sparse, thin setae, dorsal surface with scattered, moderately short setae; ventral surface also with few tufts of setae; proximal half of cutting edge with 1 or 2 prominent calcareous teeth, frequently separated by 1 or 2 smaller calcareous teeth, distal half with row of small corneous teeth, terminating in small corneous claw. Palm somewhat dorsoventrally swollen; slightly shorter to approximately equal to length of carpus; dorsomesial and dorsolateral margins each with row of very small granules or tubercles, dorsal surface convex, unarmed or with short row of tiny granules or spinules in midline proximally, and scattered short, thin setae; rounded mesial, lateral and ventral surfaces each with few scattered short, fine setae. Cutting edge of fixed finger with 2 or 3 large calcareous teeth proximally and row of small calcareous teeth distally, terminating in small calcareous claw. Carpus with row of moderately small, acute spines on dorsomesial margin, 1 or 2 small spines mesially on distal margin, second row of spines beginning at dorsolateral margin proximally but becoming median at distal margin, dorsal surface laterad of median spine-row sloping laterally, dorsolateral margin not delimited; mesial and lateral surfaces each with few individual capsulate setae to several short, transverse rows of closely-spaced, capsulate setae; ventromesial and ventrolateral margins rounded, ventral surface minutely granular or spinulose. Merus with row of capsulate setae on dorsodistal margin and often extending onto mesioand laterodistal margins; dorsal, lateral and mesial surfaces unarmed but with few scattered, very short, stiff bristles; ventromesial and ventrolateral margins and ventral surface minutely tuberculate or granulate, ventrolateral distal angle with 1-4 tiny spinules. Ischium unarmed.

Left cheliped (Figures 2c, d) with long, slender dactyl and fixed finger, frequently curving ventrally, with or without hiatus; margins of neither dactyl nor fixed finger delimited, rounded surfaces unarmed but with numerous short, thin setae, often forming sparse longitudinal row on mesial face of dactyl; cutting edges each with row of small, corneous teeth. Palm equal to or slightly shorter than carpus; dorsomesial and dorsolateral margins each with row of very small granules or tubercles, latter not extending onto fixed finger, dorsal surface weakly convex, dorsal midline with short row of tiny spines or spinules, at least in proximal half; ventral surface with scattered, moderately short, fine setae. Carpus with dorsal surface relatively flat, armed with few tiny spines, dorsomesial and dorsolateral margins each with row of small spines, largest laterally; mesial and lateral faces each with either short, coarse bristles or capsulate setae, latter forming short transverse rows in holotype; ventrolateral distal margin with 1 or 2 small spines in distal half, ventromesial margin with 2-4 tiny spinules or tubercles distally; ventral surface granular or tuberculate. Merus with row of capsulate setae on dorsodistal margin, dorsal surface unarmed but with few short, stiff bristles and few longer thin setae, lateral and ventral surfaces unarmed, ventrolateral and ventromesial margins each with row of very small tubercles or subacute spinules, ventrolateral margin with 1 additional more prominent spine distally; ventral surface tuberculate or granular. Ischium unarmed.

Ambulatory legs (Figures $2 \mathrm{e}, \mathrm{f}$ ) similar from left to right; very little difference in lengths of second and third ischia. Dactyls very slightly shorter to slightly longer than propodi; dorsal surfaces each with row of closely-set, long, moderately stiff setae; mesial faces each very weakly concave; ventral margins each with row of moderately stiff setae (frequently directed upward and not visible in lateral view) and 5-9 rather widely-spaced, very small, corneous spines. Propodi each with 1 dorsal and 1 ventral row of long setae. Carpi each with mixed row of small and very small spines on dorsal surface, dorsodistal spine largest. Meri each with low protuberances and few short, spiniform bristles on dorsal surface; ventral margins each spinulose. Ischia unarmed, but each with tuft of setae on lateral face. Dactyls of fourth pereopods with very short claws. Fifth pereopods chelate.

Sternite of third pereopods broad; anterior lobe narrowly subrectangular, unarmed.

Coxae of fifth pereopods in males with long right sexual tube (Figure 1f), proximal portion stout, curving posteriorly and externally; elongate distal portion tapering and becoming filiform; left sexual tube very short, with terminal tuft of setae. Coxae of fifth pereopods of females (Figure $1 \mathrm{~g}$ ) each with tuft of long setae distally, densest on left; 2segmented, paired first pleopods each with terminal setae.

Telson (Figure $2 \mathrm{~g}$ ) with prominent median cleft separating rounded posterior lobes; terminal and lateral margins each with row of closely-spaced, small or very small corneous, bristle-like spines.

\section{Color}

Unknown.

\section{Habitat}

Unknown

\section{Distribution}

Known only from northwestern Australia, off Cape Cuvier and North West Cape; 134-140 m.

\section{Etymology}

This species is named for Dr. Gary J. Morgan, 
former curator of Crustacea and now executive director of the Western Australian Museum, in recognition of his major contributions both to paguroid systematics and the growth and success of the museum.

\section{Variation}

Because of the conditions of the paratypes, it has not been possible to adequately assess potential sexual dimorphism. However, of the four paratypes from station Dm6/192/63, two are ovigerous females and two are males. While there is only one right cheliped among their appendages, there are three left. One, presumably belonging to one of the males, agrees with the male holotype in having an elongate and ventrally curved dactyl and fixed finger; the mesial and lateral faces of the carpus each have several short, transverse rows of capsulate setae. The dactyls and fixed fingers of remaining two left chelipeds are shorter and are not curved; the lateral and mesial faces of the carpi have scattered short, stiff, bristlelike setae, but lack capsulate setae. Despite the 0.4 $\mathrm{mm}$ difference in shield lengths between the smallest male and largest female, all four specimens vary little in actual size, because shield width more than length seems to increase with growth. Although the differences observed among the four left chelipeds may represent sexual dimorphism, both in the lengthening and curvature of the dactyl and fixed finger and in the development of capsulate setae on the carpus in $C$. morgani, sp. nov., this cannot be ascertained from the limited material presently available. A similar elongation of the left cheliped was found to represent allometric growth rather than sexual dimorphism in Bythiopagurus macrocolus McLaughlin, 2003b.

Specialized capsulate structures are known to develop on the spines of the chelipeds in Nematopagurus spinulosensoris McLaughlin and Brock, 1974, and seemingly similar structures have been reported on the spines and/or tubercles in a few species of Pagurus (cf. McLaughlin, 1997). Simple capsulate setae are known to develop on the third through fifth sternites in several genera (cf. McLaughlin, 1981). The presence of what appear to be capsulate setae on the lateral and mesial faces of the carpi of the chelipeds is described for the first time in $C$. morgani, sp. nov. Unfortunately, the paucity and poor condition of these chelipeds precluded any detailed examination of the capsulate structures; however, their development appeared to be growth related. Very limited observations suggested that stiff bristle-like structures in particular positions on one individual had developed into capsulate setae in the same position on a second specimen.

\section{Affinities}

As indicated previously, Cycetopagurus gen. nov., and its type species, C. morgani, sp. nov., share characters with several other genera and species of the Paguridae. However, neither the genus, nor the species can be considered closely related to any specific taxa. In addition to the similarities mentioned at the generic level, the ambulatory dactyls and propodi of $C$. morgani, with their fringes of long setae, are suggestive of species of Spiropagurus Stimpson, whereas the armature of the carpi is reminiscent of species of Catapagurus A. Milne-Edwards. Cycetopagurus morgani is immediately distinguished from all known species by the armature of the telson. However, in the absence of the telson, the suite of characters that define this taxon, when taken collectively, assure its recognition.

\section{DISCUSSION}

Of the 69 genera of the Paguridae reviewed by McLaughlin (2003a), males of 35 genera were characterized as developing of one or a pair of sexual tubes, and at least some species in an additional six genera showed evidence of papillae or very short protuberances of the vas deferens from one or both coxae. Cycetopagurus, gen. nov., is one of 18 genera in which at least some species develop paired sexual tubes, with the right as long as or longer than the left. Although the right sexual tube can be categorized as long ( $>5$ coxal lengths) in nine of these genera, it is terminally filamentous in just four, including Cycetopagurus. Extensions of the vas deferens into penes or sexual tubes occur in both brachyuran and paguroid crabs but appear to represent different evolutionary mechanisms. The brachyuran penes function in association with the male paired first and second pleopods, sexually modified for sperm transfer (Guinot and Tavares, 2003). No paired and sexually modified male pleopods are present in paguroid taxa in which sexual tubes develop. Whether these tubes in pagurids function in sperm transfer has not been documented in living animals. However, de Saint Laurent (1968), García-Gómez (1988) and Tudge and Lemaitre (in press) have recorded the presence of spermatophores in the sexual tubes of Decaphyllus junquai de Saint Laurent, 1968, Enneobranchus flavioculatus García-Gómez, 1988, and Micropagurus acantholepis (Stimpson, 1858), respectively.

Hazlett (1968), reporting on observed copulations in Anapagurus chiroacanthus (Lilljeborg, 1856) and $A$. breviaculeatus Fenizia, 1937, stated that the mating pairs were "in very close contact, genital orifices touching in copula." Hazlett (1968) noted that in contrast to species of Pagurus Fabricius, males of Anapagurus Henderson species each had a "tubular 
projection" of the vas deferens on the coxa of the fifth pereopod. Hazlett concluded that internal fertilization seemed especially possible from the observed behavior "- genital contact in copula" in species of Anapagurus. However, Guinot and Tavares (2003), quoting personal communication from Lemaitre and Tudge, suggested that insemination in hermit crabs was external because spermatophores had been observed attached to various parts of the [female] bodies in species with male sexual tubes.

Tudge and Lemaitre (in press), in the first study of the micro- and ultrastructure of a pagurid sexual tube, examined the sexual tube of $M$. acantholepis and refuted the earlier hypotheses that the pagurid sexual tube was a simple extension of the vas deferens (Henderson, 1888; Alcock, 1905; Fenizia, 1937). Tudge and Lemaitre (in press) found that while the tube of $M$. acantholepis was a functional extension of the vas deferens, it was encased in a structural elongation of the coxal segment. They also suggested that the terminal opening of the tube was capable of considerable expansion to allow the preformed, tripartite spermatophore (Tudge, 1999) to exit.

The sexual tubes of males of Decaphyllus, Enneobranchus, Micropagurus, and Anapagurus, while narrower terminally than basally, are unquestionably not filiform, thus expansion to permit spermatophore discharge would certainly be feasible. However, in Nematopaguroides, Cycetopagurus, gen. nov., and similar genera, dilation of such a slender tube over considerable length seems improbable. De Saint LaurentDechancé (1966) reported dimorphism in spermatophores in the paired sexual tubes of species of Iridopagurus de Saint Laurent-Dechancé. It might also be possible that the sexual tubes themselves, when paired, serve different functions for the male. In the sessile barnacle, Semibalanus balanoides (Linnaeus, 1767), for example, the penis of a functional male has two roles. Prior to copulation and insemination, the penis reportedly "searches" and "tests" the substrate for a functional female (Barnes and Barnes, 1956; Barnes et al., 1977). It is conceivable that the rather whip-like sexual tube characteristic of species in genera such as Cycetopagurus serves a function as yet undetermined, whereas the shorter tube participates in actual spermatophore transfer.

\section{ACKNOWLEDGEMENTS}

The author acknowledges, with deep gratitude, the sharing of information on this genus that was provided by the late Mme de Saint Laurent during the author's first visit to the Muséum national d'Histoire naturelle. She also is indebted to Drs Alain Crosnier, USM Taxonomie-Collections,
Department Systématique et Évolution, and Diana Jones, Curator of Crustacea, Western Australian Museum, for making the material available for completion of the study. This is a scientific contribution from the Shannon Point Marine Center, Western Washington University.

\section{REFERENCES}

Alcock, A. (1905). Anomura. Fasc. I. Pagurides. Catalogue of the Indian decapod Crustacea in the collections of the Indian Museum, 2: 1-197. Indian Museum, Calcutta.

Barnes, H. and Barnes, M. (1956). The formation of the egg-mass in Balanus balanoides (L.). Archivum Societatis Zoologicae Botanicae Fennicae "Vanamo" 11: 11-16.

Barnes, H., Barnes, M. and Klepal, W. (1977). Studies on the reproduction of cirripedes. I. Introduction: copulation, release of oocytes, and formation of the egg lamellae. Journal of Experimental Marine Biology and Ecology 27: 195-218.

Fenizia, G. (1937). I Paguridi del golfo di Napoli. 2 Contributo. Specie e varietá dei generi Catapaguroides M. Edwards e Bouvier, Anapagurus Henderson et Nematopagurus M. Edwards e Bouvier. Annuario del Museo Zoologico della R. Universitá di Napoli (Nuova Serie) $7(2): 1-40$.

García-Gómez, J. (1988). A new genus and three new species of hermit crabs (Crustacea: Decapoda: Paguridae) from the western Atlantic Ocean. Bulletin of Marine Science 42: 44-64.

Guinot, D. and Tavares, M. (2003). A new subfamilial arrangement for the Dromiidae de Haan, 1833, with diagnoses and descriptions of new genera and species (Crustacea, Decapoda, Brachyura). Zoosystema 25: 43129.

Hazlett, B.A. (1968). The sexual behavior of some European hermit crabs (Anomura: Paguridae). Pubblicazioni della Stazione Zoologica di Napoli 36: 238252.

Henderson, J.R. (1888). Report on the Anomura collected by H.M.S. Challenger during the years 1873-76. Scientific Results of the Exploratory Voyage of HMS Challenger, (Zoology) 27: 1-221. Her Majesty's Stationary Office, Edinburgh etc.

Lemaitre, R. (1994). Crustacea Decapoda: Deep-water hermit crabs (Parapaguridae) from French Polnesia with descriptions of four new species. In: A. Crosnier (ed.). Résultats des campagnes MUSORSTOM, 12. Mémoirs de Muséum national d'Histoire naturelle, Paris 161: 375-419.

Lemaitre, R. (1996). Hermit crabs of the family Parapaguridae (Crustacea: Decapoda: Anomura) from Australia: Species of Strobopagurus Lemaitre, 1989, Sympagurus Smith, 1883 and two new genera. Records of the Australian Museum 48: 163-221.

Lemaitre, R. (1999). Crustacea Decapoda: A review of the species of the genus Parapagurus Smith, 1879 (Parapaguridae) from the Pacific and Indian Oceans. In: A. Crosnier (ed.). Résultats des Campagnes MUSORSTOM, 20. Mémoires du Muséum national $d^{\prime}$ Histoire naturelle 180: 303-378.

Lemaitre, R. (2004). Crustacea Decapoda: A worldwide 
review of the hermit crab species of the genus Sympagurus Smith, 1883. In: B. Marshall and B. Richer de Forges (eds). Tropical Deep-Sea Benthos, 23. Mémoires du Muséum national d'Histoire naturelle 191: 85-149.

Lilljeborg, W. (1856). Om Hafs-Crustaceer vid Kullaberg i Skåne. (Crustacea marina ad Kullaberg in Scania mense Julii 1852 collecta.). Ofversigt af Kongliga Vetenskapsakademiens Forhandlingar. Stockholm 12: 117138.

Linnaeus, C. (1767). Systema Naturae per Regna Tria Naturae, Secundum Classes, Ordines, Genera, Species cum Characteribus, Differentiis, Synonymis, Locis. Edition 12, 1(2), Pp. 533-1327. Holmiae.

McLaughlin, P.A. (1981). Revision of Pylopagurus and Tomopagurus (Crustacea: Decapoda: Paguridae), with the descriptions of new genera and species: Part I. Ten new genera of the Paguridae and a redescription of Tomopagurus A. Milne Edwards and Bouvier. Bulletin of Marine Science 31: 1-30.

McLaughlin, P.A. (1997). Crustacea Decapoda: Hermit crabs of the family Paguridae from the KARUBAR cruise in Indonesia. In: A. Crosnier and P. Bouchet (eds), Résultats des Campagnes MUSORSTOM, 16. Mémoires du Muséum national d'Histoire naturelle 172: 433-572

McLaughlin, P.A. (2003a). Illustrated keys to the families and genera of the superfamily Paguroidea (Crustacea: Decapoda; Anomura), with diagnoses of the genera of Paguridae. In: R. Lemaitre and C.C. Tudge (eds). Biology of the Anomura. Proceedings of a symposium at the Fifth International Crustacean Congress, Melbourne, Australia, 9-13 July 2001. Memoirs of Museum Victoria 60: 111-144.

McLaughlin, P.A. (2003b). A new genus and species of hermit crab (Decapoda: Anomura: Paguroidea: Paguridae) from the seamount region of southeastern Tasmanian. Memoirs of Museum Victoria 60: 229-236.
McLaughlin, P.A. (2004). A reappraisal of the hermit crab genera Catapagurus A. Milne-Edwards and Hemipagurus Smith (Decapoda: Anomura: Paguroidea: Paguridae), with the description of a new species. Zootaxa 433: 1-16.

McLaughlin, P.A. and Brock, J.H. (1974). A new species of hermit crab of the genus Nematopagurus (Crustacea: Decapoda: Paguridae) from Hawaii. Proceedings of the Biological Society of Washington 84: 245-256.

Saint Laurent, M. de. (1968). Révision des genres Catapaguroides et Cestopagurus et description de quatre genres nouveaux. I. Catapaguroides A. Milne Edwards et Bouvier 'et Decaphyllus nov. gen. (Crustacés Décapodes Paguridae) (suite). Bulletin du Muséum national d'Histoire naturelle (2) 39 (1967): 1100-1119.

Saint Laurent-Dechancé, M. de. (1966). Iridopagurus, genre nouveau de Paguridae (Crustacés Décapodes) des mers tropicales américaines. Bulletin du Muséum national d'Histoire naturelle (2) 38: 151-173.

Stimpson, W. (1858). Prodromus descriptionis animalium evertebratorum, quae in expeditione ad Oceanum Pacificum Septentrionalem, a Republica Federate missa, Cadwaladaro Ringgold et Johanne Rodgers Ducibus, observavit et descripsit. VII. [Preprint (December 1858) from] Proceedings of the Academy of Natural Sciences of Philadelphia 1858 [1859]: 225-252.

Tudge, C.C. (1999). Spermatophore morphology in the hermit crab families Paguridae and Parapaguridae (Paguroidea, Anomura, Decapoda). Invertebrate Reproduction and Development 35: 203-214.

Tudge, C.C. and Lemaitre, $R$. (in press). Studies of male sexual tubes in the hermit crabs (Crustacea, Decapoda, Anomura, Paguroidea) I. Morphology of the sexual tube in Micropagurus acantholepis (Stimpson, 1858), with comments on function and evolution. Journal of Morphology.

Manuscript received 8 September 2003; accepted 16 January 2004 